\title{
Replicating an Elite-Driven Approach/ Elite Dominance in Intangible Cultural Heritage Safeguarding: The Role of Local Government-Scholar Networks in China
}

(Christina Maags and Heike Holbig)

\begin{abstract}
:
Since "intangible cultural heritage" $(\mathrm{ICH})$ became the new focal point in the global heritage discourse, governments and scholars in many countries have commenced to promote this new form of "immaterial" culture. The People's Republic of China has been one of the most active state parties, implementing the new scheme and adapting it to domestic discourses and practices. Here, policies formulated at the national level become increasingly malleable to the interests of local government-scholar networks. By conducting a comparative case study of two provinces, this paper aims to identify the role of local elite networks in the domestic implementation of the 2003 UNESCO Convention, focusing on the incentives of scholars and officials to participate in $\mathrm{ICH}$ policy networks. It finds that the implementation of the Convention has not removed the power asymmetry between elite and popular actors instead fostering an elite-driven policy approach shaped by symbiotic, mutually legitimizing government-scholar networks.
\end{abstract}

\section{Introduction}

Since "intangible cultural heritage" $(\mathrm{ICH})$ became the new focal point in the global heritage discourse with the institutionalization of the UNESCO Convention for the Safeguarding of Intangible Cultural Heritage in 2003 (hereafter: "the Convention"), governments and scholars in many countries have commenced to promote this new form of "immaterial" or "living" culture. Governments worldwide now compete to have their countries' ICH inscribed at UNESCO, which defines $\mathrm{ICH}$ as "practices, representations, expressions, knowledge, skills - as well as the instruments, objects, artefacts and cultural spaces associated therewith - that communities, groups and, in some cases, individuals recognize as part of their cultural heritage" (UNESCO 2003). ${ }^{1}$ To identify and promote $\mathrm{ICH}$ items, governments, academics, professionals, and other actors at central and local levels have developed multiple strategies and adapted them to national contexts resulting in considerable variations in $\mathrm{ICH}$ policies. The People's Republic of China (PRC), which ratified the Convention in 2004, has been one of the most active state parties, 
implementing the new scheme and adapting it to domestic discourses and practices, opening new spaces for collective calls to promote cultural heritage and for negotiating its social value.

The Convention, however, involves a certain tension between the normative claim to include local communities in selecting and nominating their $\mathrm{ICH}$ on the one hand and the functional requirements of $\mathrm{ICH}$ safeguarding ${ }^{2}$ on the other. Scholars such as Lixinski or Lenzerini, for example, have applauded the Convention for emphasizing the active role of local actors in principle, but have criticized it for leaving the responsibility for involving local communities to the state, potentially depriving them of their cultural human rights. ${ }^{3}$ This tension has also been observed in the Chinese case. As Yu Hua has argued, ICH safeguarding "[...] requires officials and experts who should know how to research, preserve, protect, promote, enhance, transmit, educate and revitalise various aspects of heritage to fulfil the requirements of their job", ${ }^{4}$ making expert knowledge essential in the $\mathrm{ICH}$ policy work. Yet, this elite-driven approach also marginalizes vernacular understandings and practices of $\mathrm{ICH}$ safeguarding. Similarly, studies by Fan Li and Yan Haiming have pointed to a lack of local communities' involvement in the conservation of tangible heritage ${ }^{5}$ As Yan has noted, heritage conservation in China "privileges expert knowledge over local voices, while it empowers government by ignoring local residents' capability within heritage conservation". ${ }^{6}$

Overall, given the expectations that ICH would give voice to local communities, the Chinese case appears as a highly ambiguous one. On the one hand, we find a striking degree of variation in the $\mathrm{ICH}$ policies, governmental regulations and guidelines across administrative levels as well as fascinatingly vibrant local initiatives, spearheaded by local actors, in the field of ICH safeguarding and promotion. This pattern confirms findings indicating that a growing number of new actors are entering the policy-making scene in China, leading to what has been described as "fragmented authoritarianism." 7 This is a conceptual framework to dynamically analyze how, in an authoritarian context, policies formulated at the national level become increasingly malleable to the interests and goals of lower-level agencies implementing these policies. On the other hand, when we look more closely at these new actors we observe a dense web of symbiotic networks 
between local cadres and scholars, which suggests a highly elite-driven approach to formulating and implementing $\mathrm{ICH}$ policies. ${ }^{8}$

While elite dominance per se might not be surprising in the context of an authoritarian party-state, we have to ask ourselves whether this increasing variety of new actors is indeed leading to the "increasing pluralization" of the Chinese policy-making process in the sense of creating spaces for "policy entrepreneurs" to voice open contestation, as predicted by Andrew Mertha. ${ }^{9}$ An analysis of government-scholarly cooperation in safeguarding $\mathrm{ICH}$ is therefore not only relevant as it adds to the understanding of growing pluralization in the Chinese policy process, but it also depicts a country-specific variation of implementing the ICH Convention.

This paper aims to shed light on the role of local elite networks in the domestic implementation of the 2003 UNESCO Convention. It addresses the following questions: (1) What incentives exist for local officials and scholars to participate in networks within the field of $\mathrm{ICH}$ policies? (2) What contribution do scholars and other $\mathrm{ICH}$ experts make within these networks? (3) What does the outcome of local ICH policies tell us about the functioning of fragmented authoritarianism and the prospects for pluralization versus the emergence of a new expertocracy shaping the discourse in this policy field?

To answer these questions, this paper conducts a comparative case study of Jiangsu and Fujian provinces. After familiarizing the reader with the Chinese academic discourse on $\mathrm{ICH}$, we briefly outline the Chinese policy process. By comparing four different local governments' ICH policies in the area of $\mathrm{ICH}$ safeguarding and tourism, our findings demonstrate how $\mathrm{ICH}$ strategies diffuse horizontally and vertically, leading to variations in local ICH activities and location branding. One source of these variations, we argue, are symbiotic networks between government cadres and scholars who cooperate for the sake of strategically positioning their locality vis-à-vis national and international audiences.

\section{China's adoption of the 2003 UNESCO ICH Convention}

To establish a national identity, Western European countries began promoting the protection of cultural heritage since the eighteenth century, ${ }^{10}$ a practice later manifested in UNESCO's World 
Heritage Convention of 1972 . Here, UNESCO categorized cultural heritage into "monuments, groups of buildings and sites of outstanding universal value." ${ }^{11}$ Yet, as the 1972 Convention only included the protection of tangible forms of culture, it was increasingly criticized in the 1970 s and 1980s, particularly by developing countries. ${ }^{12}$ After preliminary attempts by the UNESCO to introduce $\mathrm{ICH}$ safeguarding in $1989^{13}$ and $2001,{ }^{14}$ albeit in legally unbinding forms, ${ }^{15}$ the organization eventually established the $\mathrm{ICH}$ Convention in $2003^{16}$. How to safeguard and further develop $\mathrm{ICH}$, and whether or not the $\mathrm{ICH}$ Convention achieves its aims, however, are still subjects to debates, both internationally and domestically. ${ }^{17}$

In the PRC as elsewhere, international conceptualizations have triggered new domestic discourses on the protection of traditional culture. After the party-state had loosened its grip over the cultural realm during the Reform and Opening Up period, the concept of "cultural heritage" (wénhuà yíchăn) gained currency during the 1980s and 1990s. Until then the Chinese academia had pursued the concept of "folk culture" (mínsú wénhuà or mínjiān wénhuà), which refers to traditional cultural customs, including their tangible cultural manifestations and surrounding natural setting. ${ }^{18} \mathrm{~A}$ content analysis of over 1,000 articles on the Cross Asia database conducted by the authors has shown that the Chinese discourse on cultural tourism was also framed in accordance with these two terms from the early 1990s onwards. "Folk culture tourism" (mínsú or mínjiān wénhuà lǘyóu) was used to describe cultural tourism activities in historical districts or villages. ${ }^{19}$ The concept of "cultural heritage tourism" (wénhuà yíchăn lǚyóu) was initially only associated with UNESCO world heritage sites. After the PRC ratified the ICH Convention, a broader application of the cultural heritage concept gained ground in China, especially in terms of "intangible cultural heritage" (fēiwùzhí wénhuà yíchăn or wúxíng wénhuà yíchăn), leading to adaptations and the blurring of the concepts of "cultural heritage tourism" and "folk culture tourism" in academic discourse. ${ }^{20}$ Since 2006 , studies have specifically concentrated on how to develop "intangible cultural heritage tourism" (fēiwùzhí wénhuà yíchăn lǚyóu) provincially and locally. ${ }^{21}$

\section{Incentives for local actors under fragmented authoritarianism}

The policy-making process of the PRC has commonly been characterized by fragmented authoritarianism. According to Lieberthal and Oksenberg, "what appears on paper to be a unified, 
hierarchical chain of command turns out in reality to be divided, segmented and stratified."22 This fragmentation of authority is the result of decentralization, which has provided the "local" level that is, provincial, municipal, or county governments - with greater leeway in policy implementation. Fragmentation takes place along vertical lines of command (tiáo), as central policies are "watered down" during their top-down implementation within the administrative hierarchy, as well as horizontally across various bureaucracies at the same level (kuài) that compete and negotiate with each other. Thus, despite nationally established agendas, local policies are shaped by local actors' long-term interests. ${ }^{23}$ In a variation of the fragmented authoritarianism model, entitled "fragmented authoritarianism 2.0," Andrew Mertha emphasizes that while non-state actors are increasingly entering the local policy process, local levels also apply concepts and strategies developed at the national level to bolster local implementation schemes. ${ }^{24}$ As this paper shows, besides referring to domestic concepts, state and non-state actors also utilize international concepts and strategies to pursue local interests.

Within the framework of fragmented authoritarianism, localities have various incentives to compete with each other for support from higher-level governments, particularly from the national government. Strong incentives for local initiatives emerge, for instance, when the central government plans to engage in policy experimentation. Heilmann has shown that the party-state develops new policies by letting local governments explore potential policy measures on a small scale so as to utilize successful policies on a larger basis. By issuing "experimental regulations," allowing "experimental points" (models and pilot projects), or granting jurisdictions greater discretionary powers in an "experimental zone," the PRC engages in policy "experimentation under hierarchy." Local knowledge and initiative are hereby rewarded within the cadre evaluation system determining the career of party and government officials. ${ }^{25}$

While this competitive feature of policy experimentation is a general incentive for the emergence of local expert networks across policy fields, more specific incentives can be identified in the field of $\mathrm{ICH}$ policy. The use of expert knowledge in $\mathrm{ICH}$ safeguarding is explicitly stipulated in UNESCO's operational guidelines. ${ }^{26}$ Looking at the literature, we find that scholarly expertise indeed plays a prominent role in local experimentation. While Svensson and Liang confirm that 
local experts have been significant in initiating innovative policies and highlighting cultural heritage in need of protection, ${ }^{27}$ Xiamen scholar Wei Chengyuan holds a rather skeptical view. He finds scholarly influence to be quite limited due to the differing opinions of officials and scholars concerning the specific modes of protection. ${ }^{28}$ Although cadres' political considerations outweigh scholarly expertise in the bargaining process, ${ }^{29}$ we nevertheless assume that the fragmented authoritarian regime creates significant incentives for interaction between local cadres and scholars in the field of $\mathrm{ICH}$ policy.

Within the vertical dimension of $\mathrm{ICH}$ policy implementation, subordinate governmental levels rely on local expert advice to assist them in appropriating concepts and strategies from the national or international level. These concepts and strategies are then used to maximize their chances of success in competing for policy experiments and fostering the local economy. Within the horizontal dimension, local officials seek local ICH experts' support through publications or interactions at conferences and research centers in order to bestow local policy-making with a "scientific" aura of academic expertise. Notably, by adopting nationally promoted concepts and strategies into their recommendations, local officials may justify the pursuit of local (economic) interests while simultaneously legitimizing the official discourse. On the other side of this symbiotic relationship, $\mathrm{ICH}$ experts may themselves obtain social legitimacy through governmental recognition, thus reinforcing the networks.

To understand the role of these symbiotic government-scholar networks in formulating and implementing $\mathrm{ICH}$ policies, this study systematically compares two provinces - namely, Jiangsu and Fujian provinces. These provinces have been selected because, firstly, both stand out in academic discourse in terms of the number of scholarly articles on the safeguarding and promotion of cultural heritage and, secondly, both have played a special role in developing $\mathrm{ICH}$ policies in China. Whereas Jiangsu has been a forerunner in $\mathrm{ICH}$ safeguarding and promotion, Fujian province has developed local ICH resources catering to Taiwanese tourists' tastes. Two localities in each province, Nanjing and Changzhou cities in Jiangsu and Fuzhou and Quanzhou cities in Fujian, are comparatively examined. The four case studies have been chosen as (1) they are in close geographical proximity and subject to the same superordinate regulations and (2) 
they enable a comparison between a provincial capital (Fuzhou; Nanjing) and a regular municipality (Quanzhou; Changzhou) within the same province and across the two provinces. In addition to the spatial comparison, the design also allows for a temporal analysis, which begins with the ICH Convention's ratification in 2004 and ends with 2014. The scholarly publications analyzed were identified through full-text searches of the China Academic Journals Network, available via Cross Asia. The government documents were retrieved from official government websites.

\section{$4 \quad$ Research findings}

\subsection{The vertical dimension of ICH concept and strategy formulation}

Since ratifying the $\mathrm{ICH}$ Convention, several national-level agencies and ministries have produced guidelines for protecting traditional cultural heritage $(\mathrm{TCH})$ and $\mathrm{ICH}$, including its tangible environment. These bodies include the State Council, the Ministry of Culture (MOC), the State Administration of Cultural Heritage (SACH) and the National Tourism Administration (NTA). The State Council has issued a number of notices concerning folk culture (2005), cultural heritage (2004-2005) and ICH (2006-2008). ${ }^{30}$ These documents stipulate why Chinese cultural heritage needs to be protected and which measures and national targets should be achieved by all subordinate governmental levels. ${ }^{31}$ The State Council's "Interim Measures on the Management and Protection of Intangible Cultural Heritage" of 2006 specify local governments' obligations to safeguard $\mathrm{ICH}$, while $\mathrm{ICH}$ tourism is only mentioned for $\mathrm{ICH}$ development. While they resemble the $\mathrm{ICH}$ Convention, these guidelines are also tailored to the Chinese political system - for example, by coinciding with ten-year (and later five-year) plans or adopting measures that correspond to specific levels of government. ${ }^{32}$

In addition, various subordinate ministries and affiliated organs, often jointly, issue guidelines for how to safeguard $\mathrm{ICH}$, reconfirming and enlarging the scope of the State Council's stipulations. While many ministries, such as the Ministry of Construction or the Ministry of Education, supervise certain aspects of cultural heritage-related work, it is mainly the MOC which supervises the nationwide $\mathrm{ICH}$ safeguarding ${ }^{33}$ Subordinate organs create county, municipal or 
provincial lists of $\mathrm{ICH}$ items to be considered by the $\mathrm{MOC}$ and the State Council for inclusion on the national list - a common prerequisite for later nomination to the UNESCO ICH representative list. ${ }^{34}$

Strategies on $\mathrm{ICH}$ safeguarding diffuse vertically and horizontally through the Chinese party-state. One of these strategies is the promotion of $\mathrm{ICH}$ tourism. In addition to promoting $\mathrm{ICH}$ safeguarding, the MOC also started to support the cultural tourism industry in 2009 by issuing a document entitled "Guidance on Joint Promotion of Culture and Tourism Development." In this document, the MOC, together with the NTA, encouraged nationwide cultural tourism promotion. In particular, the document argues for creating cultural tourism theme years, festivals, and theme parks, as well as tourist products. ${ }^{35}$ One example of a national theme year is the campaign "Beautiful China" (Měili Zhōngguó), launched in 2014, promoting various regional TCH and ICH activities. ${ }^{36}$ The 2009 MOC document also mentioned, for the first time, the use of ICH resources as the basis for cultural tourism. While simultaneously safeguarding $\mathrm{ICH}$, "cultural environment protection experimental zones" (wénhuà shēngtài băohù shíyàn qū) ${ }^{37}$ - where certain ICH policies can be explored to subsequently transform the area into a permanent protection zone promote $\mathrm{ICH}$-related activities. ${ }^{38}$ Another experimental policy initiated by the MOC in 2010 involved the creation of "demonstration bases for productive ICH protection" (fëiwùzhí wénhuà yíchăn shēngchănxìng băohù shifàn jīdi) - that is, organizing facilities that produce $\mathrm{ICH}$-related products on the basis of expert and industrial associations' recommendations. ${ }^{39}$ Finally, strategies to promote $\mathrm{ICH}$ as a tourism product have been included in the cultural industry's national five-year plan, focusing on marketing $\mathrm{ICH}$ in the form of festivals, museums and tourism routes. ${ }^{40}$

In addition to the various government organs, the Communist Party of China (CPC) also stipulates measures and objectives - thereby also disseminating ICH strategies. The 2011 "CPC Resolution on the Promotion of Socialist Culture" exemplifies this; it calls for the protection of Chinese traditional and socialist culture domestically and the promotion of China's "cultural soft power" abroad. China's cultural soft-power strategy aims to grow the cultural attractiveness of China internationally by exhibiting the country's traditional culture to a foreign audience. To 
achieve this goal, the document suggests recruiting university graduates who "are knowledgeable of their local culture ... particularly those who carry on intangible cultural heritage." 41 This again demonstrates the importance given to scholarly expertise on ICH in China.

Following $\mathrm{ICH}$ strategies disseminated by the party-state on the national level, subordinate levels of government produce their own guidelines based on national provisions and regional circumstances. Until 2005, cultural heritage protection in Jiangsu province mostly concentrated on TCH - for instance, by promoting the province's world cultural heritage (shijiè wénhuà yíchăn) or the newly introduced "heritage protection day" (yíchăn băohù ri). ${ }^{42}$ This emphasis changed in favor of $\mathrm{ICH}$ in 2005, when Jiangsu's culture bureau organized ICH exhibitions, conducted surveys, and established a pilot unit (shidiăn dānwèi) of experts recommending specific examples of $\mathrm{ICH}$ to be listed nationally. ${ }^{43}$ In 2006, the Jiangsu culture bureau published its fundamental regulations on $\mathrm{ICH}$ safeguarding and development, ${ }^{44}$ which were revised in $2013 .{ }^{45}$ In these "ICH regulations," the bureau also called for the inclusion of "expert consultation systems" (zhuānjiā zīxún zhìdù) in government decision-making regarding the safeguarding and advancement of local $\mathrm{ICH} .{ }^{46}$ Regarding vertical implementation of policies, Jiangsu province complied with national $\mathrm{ICH}$ policies by issuing its own $\mathrm{ICH}$ policies and establishing a scholarly consultation system.

Horizontally, Jiangsu province competes with other provinces for the right to establish a pilot project which yields political power and financial support for the government. Following the implementation of regulations for promoting provincial $\mathrm{ICH}$ items, $\mathrm{ICH}$ inheritors, and $\mathrm{ICH}$ museums and research institutes, ${ }^{47}$ the culture bureau obtained permission to establish a "provincial cultural environment protection experimental zone" (shěngjí wénhuà shēngtài băohù shiyàn qū) in $2013 .^{48}$ In the same year, one year before the national tourism campaign of the same name was launched, the bureau kicked off its "Beautiful Jiangsu" (Měili Jiāngsū) campaign, which aimed to promote $\mathrm{ICH}$ as a part of cultural heritage days, $\mathrm{ICH}$ exhibitions, and other publicity activities. ${ }^{49}$ Furthermore, in 2014 , the culture bureau set up Jiangsu's first "ICH research base" (fēiwùzhí wénhuà yíchăn yánjiū jīdi), where leading experts from universities and institutes engage in $\mathrm{ICH}$-related research. This concept is similar to the national "ICH protection research 
zones" (guójiājí fēiwùzhí wénhuà yíchăn băohù yánjiū jīdi) established in 2013. Two "national $\mathrm{ICH}$ protection zones" from Jiangsu were selected, together with one from Henan and one from Fujian province..$^{50}$ The culture bureau has also focused on cultural tourism since 2006 . In its ICH regulations the bureau names the use of $\mathrm{ICH}$ resources as a means for enhancing folk culture tourism services. ${ }^{51}$ By competing for permission to establish experimental policy zones and incorporating expert knowledge into the policy process, Jiangsu province thus attempts to use the fragmented authority within the system to strategically position itself domestically.

Similarly to the case in Jiangsu, Fujian's provincial culture bureau has also developed its own strategies to foster local cultural heritage and implement superordinate policies. As early as 1999, the bureau published its "Regulations for Safeguarding Intangible Cultural Heritage"52 (Fújiàn shěng wúxíng wénhuà yíchăn băohù tiáolì de yì'àn) and subsequently adopted various national measures on folk culture and $\mathrm{ICH}$ promotion, being one of the first among China's provincial governments. In a national pilot project competition, Fujian province successfully gained permission to establish the first "Minnan cultural environment protection zone" (Minnán wénhuà shēngti băohù) in $2007^{53}$ as well as "demonstration bases for productive ICH protection" in $2011,{ }^{54}$ thereby winning political power and prestige in the horizontal competition between provinces.

Since 2003, Fujian's tourism bureau has explicitly promoted its cultural tourism industry. ${ }^{55}$ In 2008 and 2009, Fujian's ICH, as well as that of other provinces, was advertised nationally through documentaries termed Beauty of China ${ }^{56}$ and Beautiful China on CCTV. ${ }^{57}$ It was also part of the tourist campaign Beautiful Fujian, which commenced in $2012^{58}$ - anticipating, and perhaps serving as a role model for the ensuing nationwide "Beautiful China" concept. ${ }^{59}$ TV series and tourism campaigns both promote the local tourism industry which in turn enhances the municipality's reputation and political power. Starting in 2011, Fujian province also explicitly mentioned the promotion of $\mathrm{ICH}$ tourism in its policy documents. ${ }^{60}$ Fujian's provincial government thus implements the top-down policies on cultural heritage while simultaneously developing its own measures, which correspond to province-specific circumstances and leverage local resources. In doing so, it may also rely on academic research from Fujian or other areas to 
generate and communicate its own "best practices" vertically and horizontally. But what incentives do subordinate governments have to formulate specific policies tailored to the local context? And how do local scholars contribute to the formulation and implementation of these policies ?

\subsection{The horizontal dimension of $\mathrm{ICH}$ concept and strategy formulation: The role of ICH official-scholar networks at the local level}

\subsubsection{The Nanjing case (Jiangsu province)}

First and foremost, local governments have to adhere to certain ICH policies from above, such as the creation of $\mathrm{ICH}$ lists and an $\mathrm{ICH}$ inheritor system. In order to implement such a system, Nanjing established an expert group in 2006 to select ICH for local inscription. Additionally, an "expert steering group" (zhuānjiā zhǐdăo zŭ) comprising local scholars in charge of leading, inspecting and approving all $\mathrm{ICH}$-related survey work was implemented - possibly supervising the expert group. ${ }^{61}$ To comply with superordinate policies, local government may rely on experts to draft a local policy solution.

$\mathrm{ICH}$ experts may also assist in recommending new ICH strategies. Nanjing municipality has undertaken various initiatives of its own: To promote its ICH nationally, it launched a TV show called Jinling ${ }^{62}$ Folklore in $2007 .{ }^{63}$ In 2011, the culture bureau issued a "Five-Year Cultural Development Plan" that stipulated the establishment of a "municipal ICH cultural environment protection zone" (shì fēiwùzhí wénhuà yíchăn shēngtài băohù qū) and the further promotion of $\mathrm{ICH}$ abroad via China Culture Years. ${ }^{64}$ Although the development of cultural tourism was called for in $2005,{ }^{65}$ the use of $\mathrm{ICH}$ as a cultural tourism resource is not explicitly referred to in later governmental papers.

The case of Nanjing demonstrates how municipal governments adhere to superordinate policy directives while also producing independent policies to promote the locality. Going beyond the requirements stipulated at the national level, the city independently promulgates the locality nationally (TV show) and internationally (China Culture Years). Furthermore, Nanjing municipality seems to focus separately on $\mathrm{ICH}$ safeguarding and cultural tourism. While the municipality 
promoted cultural tourism in $2005,{ }^{66}$ this was not included in the 2011 five-year plan, ${ }^{67}$ even though the MOC's policies explicitly addressed the advancement of $\mathrm{ICH}$ tourism in 2009. ${ }^{68}$ Through the fragmented nature of the policy process, local governments are able to promote their locality vis-à-vis domestic or international audiences.

When local governments use their leeway to develop such independent policy approaches, they may rely on other localities' experiences, which are communicated vertically and horizontally, or they may take expert knowledge into consideration. In its policy documents Nanjing's cultural bureau frequently refers to the inclusion of expert knowledge in the development of $\mathrm{ICH}$ safeguarding and tourism, which points to the existence of a scholar-government network.

In addition to participating in government-organized expert steering groups, local experts have published recommendations to support the local government in developing local ICH. Wang Xi, a researcher at the Jiangsu Drama School in Nanjing, has proposed the establishment of a financial, legal, and administrative safeguarding system for developing $\mathrm{ICH}$ activities as a tourism resource. Government subsidies and a portion of $\mathrm{ICH}$ tourism industry revenues are to be used to promote the tourism industry and safeguard ICH legally. $\mathrm{ICH}$ safeguarding is to be enhanced through new laws and the clear definition of the legal responsibilities of all the government departments involved. Furthermore, the local government is to establish a sound administrative safeguarding system that implements common procedures for $\mathrm{ICH}$-related work. Wang thus argues for the strengthening of existing governmental institutions and procedures, thus at the same time legitimizing local politics. In a second step, she proposes the further development of the performing arts, museum, and souvenir markets in order to finance these safeguarding systems, ${ }^{69}$ thus leveraging her scholarly expertise as an economist to allude to the local government's interest in advancing the local tourism industry. Finally, she recognizes the potential of $\mathrm{ICH}$ tourism revenue for $\mathrm{ICH}$ safeguarding, while emphasizing that this mutual benefit can only be sustained by effective legal and administrative measures. This latter recommendation confirms the government's responsibility to generate revenues and promote the locality. 
An academic from the Communications University of China in Nanjing, Xu Congyao, concentrates on improving souvenir products to promote and safeguard $\mathrm{ICH}$. She suggests developing products for daily use and with a distinct local style, as well as the creation of a distinct local brand and a marketing strategy that will develop brand consciousness. In her eyes, the local government can offer essential support by enhancing legal protection of $\mathrm{ICH}$ and cooperating with universities to ensure that more personnel trained in $\mathrm{ICH}$ safeguarding are "in reserve." ${ }^{0} \mathrm{By}$ emphasizing governmental competencies and the possibility of generating revenue from tourism, Xu uses her expertise on location branding to legitimize her claim vis-à-vis the local government. Ultimately, both researchers contribute to the $\mathrm{ICH}$ strategies available to the government, thus presenting opportunities for the local government to advance its position domestically and internationally.

\subsubsection{The Changzhou case (Jiangsu province)}

In contrast to the provincial capital Nanjing, Changzhou municipality has actively promoted tourism for ICH safeguarding from an early stage. While its earlier policies, in 2003 and 2004, concentrated on renovating historical streets, ${ }^{71}$ since 2005 Changzhou municipality has issued numerous policies for safeguarding ICH. Initially, the city's culture bureau attempted to safeguard local $\mathrm{ICH}$ through safeguarding projects, ${ }^{72}$ whereas its tourism bureau focused on promoting tourism by demonstrating $\mathrm{ICH}$ in "cultural representative zones" (wénhuà dàibiǎoxìng jĭngqū). ${ }^{73}$ Later, this emphasis on using tourism for $\mathrm{ICH}$ safeguarding shifted to a greater focus on cultural tourism in general, as exemplified by the launch of "Changzhou's year of cultural tourism" in $2010 .{ }^{74}$ Out of the available ICH strategies, Changzhou has thus opted for emphasizing tourism in its local ICH policy.

$\mathrm{ICH}$ scholars and experts might have assisted the locality in making and implementing this decision. With the help of an expert committee established in $2005,{ }^{75}$ the Changzhou government not only set up $\mathrm{ICH}$ representative lists and an $\mathrm{ICH}$ inheritors system but also established an "ICH museum," an "ICH protection project center" (Chángzhōu shì fēiwùzhí wénhuà yíchăn băohù gōngchéng zhōngxīn), and an "ICH exhibition center" (Chángzhōu fēiyí zhănshì guăn) within the University of Changzhou. ${ }^{76}$ In 2011, concentrating on the specific features of its local 
culture, the city founded a cultural industry zone in the Yunhe area. ${ }^{77}$ And in 2012, Jiangsu province's culture bureau recommended that Changzhou establish "demonstration bases for productive $\mathrm{ICH}$ protection," something the city has begun to put into practice. ${ }^{78}$ Interestingly, in the same year, the municipality also announced its intention to enhance its cultural soft power by promoting its $\mathrm{TCH}$ and its $\mathrm{ICH}$ abroad. ${ }^{79}$ The Changzhou government thus cooperates with experts in order to enhance its $\mathrm{ICH}$ related policy work and to increase its competitiveness for provincial policy experimentation.

Although Changzhou has followed superordinate policies, many of them were adopted after the city had already issued its own comparable policies at an earlier stage. Its adoption of policies to promote $\mathrm{ICH}$ safeguarding through tourism in 2005 as well as its 2012 policies on $\mathrm{ICH}$ as a cultural soft-power resource exemplify the municipality's individual policy approach. Here again the rationale seems to be national and international promotion of the locality in order to enhance the city's standing among China's regions and provinces. This independent approach can again potentially be explained by government-scholar interaction, since municipalities are obliged to organize expert committees and may use them for policy adoption and implementation. The fact that the city adopted policies precisely fostering the Yunhe cultural area - a common recommendation in local academic articles - suggests that scholarly-governmental networks do in fact play a role in local decision-making.

Alongside this type of policy development, Changzhou academics have recommended that the city's traditional comb manufacture, which is listed at the national level, be utilized as an ICH tourism resource. In 2009, Liu Song, Ma Jingqing, and Lü Dongyang of the Changzhou Institute of Technology (School of Economics and Management) argued for greater governmental and industrial commitment in advancing $\mathrm{ICH}$ tourism. In their opinion, the government should enhance its leadership and promote an industrial development model by establishing a leading small group (lǐngdăo xiăozŭ) on $\mathrm{ICH}$ tourism and engaging in dialogue with stakeholders. In arguing for the establishment of a small group, the authors make use of official strategies to legitimize their claims vis-à-vis the local government. This recommendation seems particularly significant as the ad hoc creation of leading groups at the national and subnational levels has 
become an official instrument for tackling the horizontal fragmentation of bureaucratic interests and reestablishing vertical control. Finally, $\mathrm{ICH}$ safeguarding is also to be furthered by raising public awareness and enhancing participation in $\mathrm{ICH}$-related activities ${ }^{80}$ - a strategy frequently referred to in UNESCO documents. ${ }^{81}$ Scholars thus attempt to enhance their standing vis-à-vis the government by legitimizing their expertise through the integration of official strategies as well as domestic and international discourses into their policy advice.

Song Bin, a researcher at Jiangsu Teachers University of Technology in Changzhou (School of Humanities and Social Science) has evaluated Changzhou's traditional comb industry as a tourism resource. In his 2012 article he highlights previous achievements of the municipal government in promoting Changzhou's comb market and proposes further steps. Since 1987, the city has not only invested heavily in the Changzhou tourism industry but has also published an extensive five-year plan to further its traditional comb industry. According to this plan, the tourism bureau is to establish a new folk museum focusing on $\mathrm{ICH}$ and a "demonstration base for productive $\mathrm{ICH}$ protection," which would see the base become an AA tourism site. ${ }^{82}$ While Song applauds these governmental measures, he also proposes the appropriation of the national listing of combs and other local $\mathrm{ICH}$ in order to promote Yunhe River culture. ${ }^{83}$ Song thus substantiates his claim and expertise by basing his recommendations on previous government activities and depicting ways to maximize the local government's status in communal politics. Song's article appears to indicate the existence of strong government-scholar networks since it promotes his own ideas by praising governmental actions.

\subsubsection{The Fuzhou case (Fujian province)}

In Fujian province, Fuzhou municipality launched a number of folk culture and cultural tourism activities during the first years of the century that mirrored Fujian province's $\mathrm{ICH}$ regulations of 1999. ${ }^{84}$ This resemblance changed in 2006 , when Fuzhou's municipality issued a document entitled "Opinion on Strengthening Protection Work on Intangible Cultural Heritage." In this document the municipality - in addition to following national stipulations - independently outlined its "ICH tourism" promotion measures. Cultural tourism, which was to include tangible and intangible cultural resources, was to be promoted by creating a cultural tourism brand. ${ }^{85}$ Notably, 
although the local government independently used the concept "ICH tourism," the term ceased to be mentioned in subsequent governmental documents. From 2007 to 2012, Fuzhou city promoted $\mathrm{ICH}$ safeguarding and tourism development by establishing a new art school, new municipal libraries, and new museums, as well as by submitting more applications for entries to the national ICH list. Starting in 2008 , the city advanced cultural tourism by advertising local Minnan culture in special tourism zones. ${ }^{86}$ Finally, and in conformance with national government documents, Fuzhou took up the "ICH tourism" concept in its five-year plan on cultural industry development, which stated, among other things, that $\mathrm{ICH}$ tourism should be promoted through academic research and "cultural environment protection zones." 87 Through focusing its local ICH policies on tourism, Fuzhou promotes location branding.

$\mathrm{ICH}$ experts seem to contribute to the drafting of these policy variants. While many of Fuzhou's $\mathrm{ICH}$-related policies are derived from national directives, the 2006 regulations on ICH tourism are unique and could be based on scholarly recommendations. Since the concepts of folklore cultural tourism and $\mathrm{ICH}$ tourism have been discussed in scholarly articles but were absent from the superordinate strategies, this could point to the potential inclusion of concepts and strategies originating from within scholar-government networks.

The local government has a number of recommendations to choose from. Cai Chaoshuang, a junior researcher from Fujian Normal University, has been particularly vocal in recommending ways to use Fuzhou's ICH resources to promote local cultural tourism, publishing a total of three articles on the topic in 2009, 2010 and 2011. In 2009, she and her co-author Bai Rushan applied the resources-markets-products (RMP) method to explore the locality's ICH resources, tourism market, and available tourism products. For the sake of sustainable tourism development, they recommended that authorities strengthen leadership, legal protection, and policies, and that they reducing overlaps in responsibilities between governmental departments. ${ }^{88}$ Cai and Bai thus based their claim on a scholarly concept or "economist expertise," the RMP method, to legitimize local politics by calling for strengthened local leadership. One year later, Cai emphasized the employment of tangible and intangible cultural resources through the combination of a "static model" of $\mathrm{ICH}$ tourism focused on $\mathrm{ICH}$ museums with a "dynamic model" that promotes 
participatory activities. ${ }^{89}$ In doing so, she made use of international concepts on $\mathrm{ICH}$ safeguarding $^{90}$ to justify her claim. In her 2012 article, Cai innovatively adapted social science concepts to argue for the creation of a public space and a private space separated by a "barrier." In the private space, tourists could join ICH tourism activities, while the private space would be reserved for the sustainable safeguarding and development of $\mathrm{ICH} .{ }^{91}$ Cai Chaoshuang's articles make numerous innovative recommendations that simultaneously apply foreign and domestic concepts while also considering existing official strategies in local government directives. While she applies the RMP model, commonly found in Chinese academia, ${ }^{92}$ to legitimize her claim regarding local government action, Cai's appropriation of international research authorizes her claims on the basis of foreign concepts.

\subsubsection{The Quanzhou case (Fujian province)}

In Quanzhou, the municipal government has also been strongly engaged in promoting its $\mathrm{ICH}$ tourism industry from an early stage. Quanzhou individually issued regulations on ICH promotion in 2003 by referring to UNESCO's Proclamation of Masterpieces of the Oral and Intangible Heritage of Humanity. In 2005, the development of cultural tourism became the local government's focus, with cultural activities such as festivals, museums, or the "Quanzhou culture week" promoted as a tourism resource. In 2007, Quanzhou succeeded in enlisting Nanyin music as an official UNESCO ICH item. A year later, the MOC selected the city to be part of the first "Minnan cultural environment protection experimental zone." Since then, local government papers have frequently mentioned Minnan culture as a means to increase "cultural soft power," especially in relation to Taiwanese tourists. ${ }^{93}$ Meanwhile, Quanzhou launched additional tourism zones from 2011 to 2012 and established an ICH research center in 2013. In the same year, the Quanzhou government published its first policy on "combining culture and tourism" by explicitly mentioning $\mathrm{ICH}$ tourism in what was a clear derivative of the $2009 \mathrm{MOC}$ document. ${ }^{94}$

The examination of Quanzhou exemplifies once more how local governments adopt national directives while at the same time using scholarly expertise to modify them. In this case, the early decision to promote regional cultural tourism demonstrates an independent attempt, potentially inspired by scholarly studies, to advance the locality. In addition, the Quanzhou government 
individually applied concepts discussed at the national level - namely, "cultural soft power" - to promote its national standing by pointing out its value in enhancing cross-strait ties. Quanzhou's policy variant thus concentrates on the promotion and protection of Minnan culture, for the sake of location branding and obtaining a good standing nationally.

In Quanzhou, a variety of local scholars recommended the promotion of Nanyin music, supposedly one of the country's oldest musical genres and listed with UNESCO, for local ICH tourism development. Examining this subject, Chen Jinhua, vice director of the College of Tourism at Huaqiang University in Quanzhou, and Zhuang Zhibin, a researcher from the School for Environmental Planning in Kaifeng, Henan province, again use the RMP method to discuss practical strategies for promoting Quanzhou's tourism resources, such as using Putonghua (standard Chinese) in Nanyin music. Furthermore, they repeat many of Cai's "best practices" for instance, creating tourism products such as tourist routes and souvenirs or increasing advertising. ${ }^{95}$ Similarly to Cai, Chen and Zhuang apply a domestic scholarly concept, the RMP method, to substantiate their claim. In addition, they advocate the stronger commercialization of Nanying music to fully make use of its status for local tourism development - a goal that local governments avidly pursue.

In his article of 2010, Huang Yijun, a junior scholar at Quanzhou Normal University, reiterates some of the abovementioned claims but emphasizes the interactive and participative character of $\mathrm{ICH}$ tourism. By enabling tourists to participate in local ICH activities, the local government can establish an $\mathrm{ICH}$ tourism brand that could function as a pilot project for subsequent regional adoption. ${ }^{96}$ In making this recommendation, Huang considers, on the one hand, the local government's incentives to respond to superordinate initiatives in implementing its own creative measures such as a pilot project. In doing so he demonstrates the value of his approach in helping the government maximize its standing in local politics. On the other hand, he supports his argument by alluding to international discourses on the participation and inclusion of locals and tourists.

In sum, while local governments do adhere to national stipulations, all the cases examined here have gone beyond these stipulations in order to successfully compete with other governmental 
units, both vertically and horizontally. Local scholars supply recommendations to local governments with the aim of maximizing local resources and standing.

By interacting within symbiotic networks, officials and scholars cooperatively utilize national and international incentive structures. When adopting national policies locally, subordinate government levels employ officially sanctioned concepts and strategies to legitimize their own policies and/or to apply for pilot projects; ultimately, they are seeking political power and financial support from the national government. In addition, local governments frequently enhance their reputation among foreign audiences, thus increasing their political power domestically. In their pursuit of power, they may appropriate local knowledge to legitimize their activities through scientific expertise. In doing so, these local governments exploit the "cleavages inside China's structure of power" ${ }^{97}$ to develop their own strategies and policies, thereby blending national directives with scholarly recommendations.

Similarly, ICH experts have specific incentives to participate in local government activities. They offer scholarly expertise and thus gain social legitimacy themselves. These experts rely on wellknown Chinese or international scientific methods as well as on official state frames (cf. Mertha) to pursue their interests and legitimize their claims vis-à-vis the government. Because both scholars and government representatives strive to secure legitimacy and power, they form highly symbiotic networks and their claims mutually reinforce each other.

The incentives for cooperation inside these symbiotic networks are both material and symbolic. On the one hand, scholars have a symbolic incentive to become members of governmental expert groups as they acquire prestige and social legitimacy. Moreover, this membership allows scholars with an intrinsic motivation to safeguard local $\mathrm{ICH}$ to participate in $\mathrm{ICH}$ safeguarding and promotion. On the other hand, the local government co-opts experts for its local ICH policy formulation and implementation, using the latter's expertise to gain permission to establish pilot zones or to strengthen local tourism branding. Furthermore, the symbiotic network as a whole is a means with which to strengthen local governmental leadership vis-à-vis the various other actors, both horizontally and vertically. In this sense, the co-optation of experts into the local policy process could also be regarded as a strategy to counter the side effects of China's fragmented 
authoritarianism: frictions and overlapping competencies between various administrative levels and bureaucratic organs at the same level of the hierarchy.

\subsection{Comparing local networks' strategies across the four cases}

The use of expert knowledge ICH-related policies is a strategy on the part of local governments for developing an independent approach and obtaining permission to implement "policy experiment" zones. Nanjing municipality established an "expert steering group" in charge of ICHrelated survey work in 2007, a concept that was also introduced by Changzhou in 2013. ${ }^{98}$ Changzhou had also previously used local expertise to advance $\mathrm{ICH}$ safeguarding and tourism, establishing an expert committee in 2005 and cooperating with Changzhou University within ICH research centers. Such cooperation with universities and local research centers also took place in Fuzhou and Quanzhou. ${ }^{99}$ Research centers, conferences, and meetings provide an arena for the scholar-government networks to interact.

In their efforts to promote $\mathrm{ICH}$ safeguarding and development, local governments also apply nationally promoted models and benefit from local policy experimentation. The city of Changzhou benefitted from being selected to establish a "demonstration base of $\mathrm{ICH}$ production." The municipality's policies here clearly emphasize the "role model significance" (diănxíng yìyi) and "demonstrative value" (shìfàn jiàzhî) ${ }^{100}$ of the site. Fuzhou and Quanzhou's experiences have also affected surrounding localities such as Anhui County (Fujian province). Anhui has learned from Quanzhou's successful "experimental zone" policies and drawn from the city's experiences in order to improve its own ICH safeguarding measures and tourism planning. ${ }^{101}$ Furthermore, the local Hakka tourism industry and Fujian's cross-strait tourism serve as models (diănfàn) for reproduction elsewhere. ${ }^{102}$ These findings suggest that municipalities not only function as competitors for national pilot projects, but also serve as an example for subordinate levels. In

local governments' experiments with new policy measures, local expertise obviously has a specific value in determining what to protect and how, thereby impacting local decision-making.

The similarity between many of the policies adopted by the four municipalities demonstrates that local governments have many incentives to adhere to superordinate governmental policies. In our comparison of the two provinces, all of the municipalities examined had adopted measures 
such as the $\mathrm{ICH}$ lists, the $\mathrm{ICH}$ inheritor program, and the cultural heritage day, as superordinate governmental levels have demanded their implementation.

Despite their similarities, all the municipalities examined have also developed their own strategies for ICH safeguarding. In Jiangsu province, Nanjing concentrated on promoting ICH safeguarding by launching a TV series, while Changzhou focused on tourism development very early on. After stipulating the use of tourism for ICH safeguarding in 2005, Changzhou later promoted cultural tourism more generally. The two municipalities' strategies to promote their culture internationally also differ. While Changzhou aims to accumulate cultural soft power, Nanjing exhibits its traditional culture abroad during the China Culture Years. The two cities within Fujian province demonstrate similarly individual approaches. While Fuzhou strived to establish an innovative ICH tourism-related policy in 2006, Quanzhou has not followed Fuzhou's lead. It only published its first $\mathrm{ICH}$ tourism development plan in 2013. Meanwhile, Quanzhou has also taken up the concept of cultural soft power, which is not mentioned in Fuzhou's policies. Table 1, below, compares the four cases.

Table 1: Comparison of policy outcomes across provinces and municipalities

\begin{tabular}{|c|c|c|c|c|}
\hline \multicolumn{5}{|c|}{ Comparison of policy outcomes } \\
\hline & \multicolumn{2}{|c|}{ Jiangsu } & \multicolumn{2}{|c|}{ Fujian } \\
\hline & Nanjing & Changzhou & Fuzhou & Quanzhou \\
\hline $\begin{array}{l}\text { Adherence to } \\
\text { superordinate } \\
\text { level }\end{array}$ & $\begin{array}{l}\text { - } \mathrm{ICH} \text { lists, } \mathrm{ICH} \\
\text { inheritors lists } \\
\text { - Expert steering group }\end{array}$ & $\begin{array}{l}\text { - } \mathrm{ICH} \text { lists, } \mathrm{ICH} \\
\text { inheritors lists } \\
\text { - Demonstration base } \\
\text { for productive ICH } \\
\text { protection } \\
\text { - Expert committee }\end{array}$ & $\begin{array}{l}\text { - } \mathrm{ICH} \text { lists, } \mathrm{ICH} \\
\text { inheritors lists } \\
\text { - Creation of tourism } \\
\text { brand } \\
\text { - New libraries and } \\
\text { museums }\end{array}$ & $\begin{array}{l}\text { - } \mathrm{ICH} \text { lists, ICH } \\
\text { inheritors lists } \\
\text { - Document on } \\
\text { "combining culture } \\
\text { with tourism" }\end{array}$ \\
\hline
\end{tabular}




\begin{tabular}{|c|c|c|c|c|}
\hline $\begin{array}{l}\text { Independent } \\
\text { policy } \\
\text { development }\end{array}$ & $\begin{array}{l}\text { - Early launch of } \\
\text { national ICH TV show } \\
\text { in } 2007 \\
\text { - Cultural environment } \\
\text { protection zone } \\
\text { - Separate } \\
\text { development of ICH } \\
\text { tourism and } \\
\text { safeguarding } \\
\text { - Participation in China } \\
\text { Culture Year }\end{array}$ & $\begin{array}{l}\text { - Early development } \\
\text { of tourism for ICH } \\
\text { safeguarding in } \\
2005 \\
\text { - Cultural tourism year } \\
\text { - Institutionalized } \\
\text { cooperation with } \\
\text { Changzhou } \\
\text { University } \\
\text { Cultural industry } \\
\text { zone } \\
\text { Goal of generating } \\
\text { "cultural soft power" }\end{array}$ & $\begin{array}{l}\text { - } \mathrm{ICH} \text { regulations and } \\
\text { development of } \mathrm{ICH} \\
\text { tourism in } 2006 \\
\text { - Aim of establishing } \\
\text { environmental } \\
\text { protection zone } \\
\text { - Promotion of Minnan } \\
\text { culture in tourism } \\
\text { zones }\end{array}$ & $\begin{array}{l}\text { - Early ICH } \\
\text { regulations in } 2003 \\
\text { - Late tourism } \\
\text { development in } 2013 \\
\text { - First Minnan cultural } \\
\text { environment } \\
\text { protection } \\
\text { experimental zone } \\
\text { - Goal of generating } \\
\text { "cultural soft power" }\end{array}$ \\
\hline
\end{tabular}

(Source: authors)

We can also observe variation across the provinces. While the municipalities examined in Jiangsu attempt to display Han Chinese culture for an international audience, Fujian's municipalities pursue a different strategy. Here, ICH policies are tailored to Taiwanese audiences through highlighting Minnan culture. In addition, ICH safeguarding and tourism promotion appear to be more strictly separated, with the importance of the latter stressed.

When we compare the two provincial capitals with the regular municipalities, the governments at the same administrative levels also display certain similarities. As provincial capitals, Nanjing and Fuzhou have focused on implementing protection zones and are marketing their locality towards a national (TV) and international audience (China Culture Years; Taiwanese tourists). In contrast, both Changzhou and Quanzhou independently implemented ICH-related policies at a very early stage and referred to national targets such as soft-power accumulation. These phenomena could possibly be explained, first, by the greater pressure on the provincial capitals to be creative and innovative in implementing new policies and, second, by the municipalities' attempts to enhance their national and international standing. 
Due to the growing fragmentation of the Chinese policy process, government representatives and scholars have formed a dense web of symbiotic networks that is based on common incentives influencing policy implementation and outcomes in the area of $\mathrm{ICH}$ safeguarding and promotion.

While scholars seek to support their own agendas by legitimizing them scientifically and via official discourses, local governments pursue similar strategies to promote their locality domestically and abroad. In pursuing these two strategies, both are influenced by domestic and international incentive structures: Local governments seek to obtain financial support, political power and an aura of expertise, and scholars use their membership in government-scholar networks to gain prestige and social legitimacy. As a result, both parties' reciprocal claims to social and political legitimacy mutually reinforce each other.

These government-scholar networks interact within expert steering groups, expert committees, conferences, or research centers, all of which provide a platform for local experts to advise local governments on local $\mathrm{ICH}$ policy implementation. In addition, scholars may make recommendations via their publications. As a consequence of this interaction, local governments obtain advice on how to advance and innovate local ICH policy implementation inside a highly competitive bureaucratic apparatus, which in turn fosters policy variation both horizontally and vertically.

Indeed, applying the "fragmented authoritarianism" model to this case provides many answers to the question of why symbiotic networks are formed and what factors influence their strategies. This study has also shown, however, that the implementation of the ICH Convention has not removed the power asymmetry between elite and popular actors. Comparable to recent findings by $\mathrm{Yu}$, Fan and Yan, the inclusion of experts into the safeguarding process appears to reduce the incentives for local governments to include local communities. ${ }^{103}$ Despite a trend of a growing variety of actors observed in the fragmented authoritarian regime of China, the functional requirements of identifying, nominating and safeguarding $\mathrm{ICH}$ have generated new windows of opportunity for an elite-driven policy approach that is shaped by symbiotic, mutually legitimizing 
government-scholar networks at the local level. Judging from our case studies, the same fragmented authoritarian regime provides strong material and symbolic incentives for local cadres and scholars to interact in order to compete with other localities. By appropriating international and domestic ICH discourses, official party language, and scientific concepts, adapting them to the local context, and combining them with their own, more or less creative strategies, these government-scholar networks strive to increase their localities' competitiveness in the domestic and international race for $\mathrm{ICH}$ safeguarding.

We should note that there are certain limitations to this study. Although our findings show that symbiotic government-scholar networks exist, they do not reveal how decisions are reached, the specific impact scholars have on the policy outcomes, or who has the most decision-making power. More studies on scholarly-governmental interaction are needed in order to obtain deeper insight into how scholars support local governments' activities and to what extent. Nevertheless, the local development of independent policies, especially in municipalities that are not as strongly influenced by top-down decision making as provincial capitals, suggests that scholarly recommendations do potentially influence local policy-making in the field of $\mathrm{ICH}$ safeguarding.

\section{Endnotes}

1. Smith 2006, 54-5, 293.

2. In this article, we use the term "safeguarding" with regard to $\mathrm{ICH}$, sticking to the wording of the 2003 UNESCO Convention to denote measures that strive to ensure the "continuous recreation and transmission" instead of "protection or conservation in the usual sense, as this may cause intangible cultural heritage to become fixed or frozen" (UNESCO 2015a). We are aware that this definition implies a conceptual distinction between "intangible" and "tangible" cultural heritage which is criticized by a number of scholars who hold that all heritage is intangible because it is to do with human values and abstract cultural meanings (we want to thank an anonymous reviewer for drawing our attention to the complex debate behind this terminology; cf. Smith 2006, 3). However, as this debate about the values behind cultural heritage is not of imminent relevance to our argument, we decided to adopt the conventional UNESCO understanding of "safeguarding" vs. "protecting" as well as of "intangible" vs. "tangible". Accordingly, we speak of "protecting"/"protection" in contexts where tangible aspects of cultural heritage are included. We should note that in the Chinese expert jargon no distinction is made between "safeguarding" and "protecting" - both are translated as băohù (usually translated as "protect(ion)" in English). This is true even for the official translation of Article 2.3 of the 2003 UNESCO Convention into Chinese (UNESCO 2015b).

3. Lixinski 2011 and Lenzerini 2011.

4. Yu 2015, 1016-1017. 
5. Fan 2014 and Yan 2015.

6. See Yan 2015, 65.

7. Lieberthal and Oksenberg 1988 and Mertha 2009.

8. China's elite-driven approach to heritage protection management has also been addressed in Zhu's work on government imposition of the concept of "authenticity" on local heritage practices.

See Zhu 2015.

9. Mertha 2009, 996.

10. Vecco 2010, 321.

11. UNESCO 1972.

12. Aikawa 2004, 138 and Aikawa-Faure 2009, 14.

13. UNESCO 1989.

14. UNESCO 2001.

15. Aikawa-Faure 2009, 21.

16. UNESCO 2003.

17. Brown 2005.

18. Li 1993, 95.

19. Li 1993, 95.

20. Compare Wang 2003.

21. Compare Huang 2010 and Cai 2010.

22. Lieberthal and Oksenberg 1988, 137.

23. Lieberthal and Oksenberg 1988, 137-145.

24. Mertha 2009, 998-999.

25. Heilmann 2008, 1-5.

26. UNESCO 2003.

27. Svensson 2006, 44 and Liang 2013, 62.

28. Wei 2012, 1.

29. Heilmann 2008, 3.

30. IHChina 2014a.

31. For a detailed index of the PRC's statutory bodies on cultural property. See Murphy 1994.

32. State Council of the PRC 2006.

33. State Council of the PRC 2006.

34. Liang 2013, 62-67.

35. PRC Ministry of Culture 2009.

36. China National Tourism Administration 2014.

37. PRC Ministry of Culture 2009.

38. PRC Ministry of Culture 2007.

39. Sichuan Provincial Government 2010.

40. PRC Ministry of Culture 2012.

41. CPC Central Committee 2011.

42. Jiangsu Culture Bureau 2004.

43. Jiangsu Culture Bureau 2005.

44. Jiangsu Provincial Government 2006.

45. Jiangsu Provincial Government 2013a.

46. Jiangsu Provincial Government 2006.

47. Jiangsu Culture Bureau 2007a and 2007b.

48. Jiangsu Provincial Government 2013b.

49. Jiangsu Culture Bureau 2013.

50. Fang 2013.

51. Jiangsu Provincial Government 2006.

52. IHChina 2014b.

53. PRC Ministry of Culture 2007.

54. Fujian Provincial Government 2011.

55. IHChina 2014b.

56. Phoenix China 2009.

57. CCTV 2013.

58. Fujian Tourism Administration 2012.

59. See for instance Sun et al. 2014. 
60. Fujian Tourism Administration 2011a.

61. Nanjing Culture Bureau 2006.

62. The city of Nanjing had previously been called "Jinling" during the Spring and Autumn periods.

See Tongnj.com 2012.

63. Nanjing Culture Bureau 2007.

64. Nanjing Culture Bureau 2011.

65. Nanjing Culture Bureau 2005.

66. Nanjing Culture Bureau 2005.

67. Nanjing Culture Bureau 2011.

68. PRC Ministry of Culture 2009.

69. Wang 2011, 84-85.

70. Xu 2013, 171-172.

71. Changzhou Tourism Bureau 2003.

72. Changzhou Culture Bureau 2005.

73. Changzhou Tourism Bureau 2005.

74. Changzhou Tourism Bureau 2010.

75. Changzhou Culture Bureau 2012.

76. Changzhou Culture Bureau 2010.

77. Changzhou Municipal Government 2011.

78. Changzhou Culture Bureau 2013.

79. Changzhou Municipal Government 2013.

80. Liu et al. 2009, 58-59.

81. Compare UNESCO 2003

82. In 2008, the Chinese tourism industry introduced a ranking system for selected tourist attractions ranging from $A$ (lowest) to AAAAA (highest) according to 10 categories. See China National Tourism Administration 2008.

83. Song 2012, 77-80.

84. IHChina 2014b.

85. Fuzhou Municipal Government 2006.

86. Fuzhou Municipal Government 2014.

87. Fuzhou Municipal Government 2012.

88. Cai and Bai 2009, 23-26.

89. Cai $2010,40-42$.

90. See IPINCH 2014.

91. Cai 2012, 28-31.

92. Compare Chen and Zhuang 2007.

93. As a large portion of the Taiwanese population historically emigrated from Fujian, the two areas share a common culture - the so-called Minnan culture. See Rubenstein 2003, 187.

94. Quanzhou Municipal Government 2014.

95. Chen and Zhuang 2007, 42-44.

96. Huang 2010, 125-129.

97. Lieberthal and Oksenberg 1988, 138.

98. Changzhou Culture Bureau 2013.

99. Quanzhou Municipal Government 2003 and Fuzhou Municipal Government 2006.

100. Changzhou Culture Bureau 2013.

101. Fujian Tourism Administration 2011b.

102. Fujian Tourism Administration 2007.

103. Yu 2015, Fan 2014, Yan 2015. 


\section{Bibliography}

Aikawa, Noriko. 2004. An Historical Overview of the Preparation of the UNESCO International Convention for the Safeguarding of the Intangible Cultural Heritage. Museum International. 56 (1-2): 137-149.

Aikawa-Faure, Noriko. From the Proclamation of Masterpieces to the Convention for the Safeguarding of Intangible Cultural Heritage. In Intangible Heritage, edited by Natsuko Akagawa and Laurajane Smith. New York: Routledge, 2009.

Brown, Michael J. 2005. Heritage Trouble: Recent Work on the Protection of Intangible Cultural Property. International Journal of Cultural Property 12: 40-61.

Cai, Chaoshuang and Rushan Bai. 2009. An RMP analysis of Fuzhou's ICH tourism (Fúzhōushì fēiwùzhí wénhuà yíchăn lüyóu RMP fēnxī). Journal of Hebei Tourism Vocational College (Héběi lǚyóu zhíyè xuéyuàn xuébào) 3: 23-26.

Cai, Chaoshuang 2010. Discussing an ICH tourism development model - taking Fuzhou as an example (Fēiwùzhí wénhuà yíchăn lǚyóu kāifā móshì tàntǎo--yǐ fúzhōu shì wéi lì). Journal of Changchun University of Science and Technology (Social Sciences Edition) (Chăngchūn lïgōng dàxué xuébào (shèhuì kēxué băn)) 24: 41-43.

2012. A ICH tourism development theory based on authenticity (Jīyú zhēnshíxìng lîlùn de fēiwùzhí wénhuà yíchăn lǘyóu kāifā yánjiū). Journal of Fuqing Branch of Fujian Normal University (Fújiànshī dà fúqīng fēnxiào xuébào) 109: 28-31.

CCTV.com. "Prize tribute for '2013 Beautiful China - Charming Wetlands' - Minjiang Wetlands national natural protection zone ("2013 Měilì zhōngguó mèilì shīdi” bānjiăng diănlǐ - mǐnjiāng hékǒu shīdì guójiājí zìrán băohùqū)". Accessed July 17, 2014. http://zmsd.cntv.cn/2013/11/15/VIDE1384522924185960.shtml. 
Changzhou Culture Bureau. 2005. "Notice on the implementation of the national folk culture protection project (Guānyú shíshī mínzú mínjiān wénhuà băohù gōngchéng de tōngzhī)". Accessed May 25, 2014. http://www.czwgx.cn/pculture/culturepolicy/2007/1107/1267.shtml.

2010. "Work summary of 2010 and work plan for 2011 (2010 Nián gōngzuò zǒngjié jí 2011 nián gōngzuò dǎsuàn)". Accessed May 15, 2014. http://www.changzhou.gov.cn/gi news/133993674049087.

2012. "Notice on adjusting members of expert committee on Changzhou's intangible cultural heritage protection work (Guānyú tiáozhěng chángzhōushì fēiwùzhí wénhuà yíchăn bǎohù gōngzuò zhuānjiā wěiyuánhuì chéngyuán de tōngzhī)". Accessed May 23, 2014. http://www.changzhou.gov.cn/gi news/970135728569487.

2013. "Notice on the Changzhou City Press and Publication Board's recommendation of Changzhou municipal intangible cultural heritage for the first productive protection demonstrative base (Chángzhōushì wénhuà guăngdiàn xīnwén chūbăn jú guānyú tuījiàn chángzhōushì dìyīpī shijí fēiwùzhí wénhuà yíchăn shēngchănxìng băohù shìfàn jīdì de tōngzhī)". Accessed May 5 , 2014. http://www.changzhou.gov.cn/gi news/604138052376342.

Changzhou Municipal Government. 2011. "Cultural and Creative Industry Development Plan (Wénhuà chuàngyì chănyè fāzhăn zhuānxiàng guīhuà)". Accessed June 6, 2014. http://www.changzhou.gov.cn/gi news/134260512398654.

2013. "2013 Changzhou municipal main work report (2013 Nián shìzhèngfǔ zhòngdiǎn gōngzuò)". Accessed June 6, 2014. http://www.changzhou.gov.cn/gi news/407135770900613.

Changzhou Tourism Bureau. 2003. "Changzhou Municipality's 2003 Plan for Tourism Work (2003 Nián quánshì lǘyóu gōngzuò jìhuà)". Accessed June 17, 2014. http://www.changzhou.gov.cn/gi news/133994027783132. 
_ 2005. "Changzhou "eleventh five-year" tourism development and the vision outline for 2020 (Chángzhōushì lǚyóuyè fāzhăn "shíyīwǔ” guīhuà jí 2020 nián yuănjǐng mùbiāo gāngyào)". Accessed June 17, 2014. http://www.changzhou.gov.cn/gi news/133994027562413.

2010. "2010 Changzhou municipal tourism industry work plan (2010 Nián chángzhōushì lǚyóuyè $\quad$ gōngzuò $\quad$ jihuà)". $\quad$ Accessed June 2014. http://www.changzhou.gov.cn/gi news/133994006019817.

Chen, Jinhua and Zhibin Zhuang. 2007. An RMP Based Analysis of Intangible Cultural Heritage Tourism Development - Taking Quanzhou Nanyin as an Example (Jīyú RMP fēnxī de fēiwùzhíwénhuà yíchăn lǚyóu kāifā yánjiū - yǐ quánzhōu nányīn wéi lì). Journal of Leshan Teachers College (Yàoshān shïfàn xuéyuàn xuébào) 22: 42-44.

China National Tourism Administration. 2008. "AAAAA scenic areas". Accessed May 23, 2014. http://en.cnta.gov.cn/html/2008-11/2008-11-16-10-27-72978.html.

2014. "Beautiful China Tourism - Intelligent Tourism Year of 2014" - Start of the Website for advancing Chinese tourism overseas ("Měilì zhōngguó zhī lǘ - 2014 zhìhuì lǚyóu nián” jì zhōngguó lǚyóu hăiwài tuīguăng wăngzhàn qǐdòng)." Accessed may 16, 2014. http://www.cnta.com/html/2014-1/2014-1-21-\%7B@hur\%7D-34-11408.html.

CPC Central Committee. 2011. "Decision of the CPC Central Committee on Central Issues Pertaining to Deepening Reform of the Cultural System and Promoting the Great Development and Flourishing of Socialist Culture". Accessed March 19, 2014. http://www.cctb.net/bygz/wxfy/201111/t20111117 30877.htm.

Fan, Li. 2014. International influence and local response: understanding community involvement in urban heritage conservation in China. International Journal of Heritage Studies. 20 (6): 651662. 
Fang, Yuan. "First batch of national ICH protection research zones' are nominated (Shǒu pī "guójiā jí fēiwùzhí wénhuà yíchăn băohù yánjiū jīdì" huò mìngmíng)". China.com. Accessed 25 April, 2014. http://guoqing.china.com.cn/2013-01/17/content 27712471.htm.

Fuzhou Municipal Government. 2006. “Fuzhou municipality’s executive opinion on strengthening ICH protection work (Fúzhōushì rénmínzhèngfǔ guānyú jiāqiáng fēiwùzhí wénhuà yíchăn băohù gōngzuò de shíshī yìjiàn)". Accessed February 13, 2014. http://china.findlaw.cn/fagui/p 1/93177.html.

_2012. "Fuzhou municipality's notice on publishing the "Twelfth five-year plan" on Fuzhou's cultural industry (Fúzhōushì rénmínzhèngfǔ guānyú yìnfā fúzhōushì wénhuà shìyè fāzhăn "shí'èrwǔ" zhuānxiàng guīhuà de tōngzhī)". Accessed February 20, 2014. http://www.fuzhou.gov.cn/zfxxgk/bmxsq/bmxx/bmxx01/gkxx/201203/t20120328 532268.htm?ty pe=szf.

2014. "Report on the national economy and society development plan (Guómín jīngji hé shèhuì fāzhăn jìhuà bàogào), (Issues 2007-2013)". Accessed February 16, 2014. http://www.fuzhou.gov.cn/zfb/xxgk/ghjh/bg/.

Fujian Provincial Government. 2011. "Notice by the Fujian culture bureau on the first selected list of $\mathrm{ICH}$ productive protection demonstrative bases (Fújiànshěng wénhuàtīng guānyú shǒupī shěngjí fēiwùzhí wénhuà yíchăn shēngchănxìng băohù shìfàn jīdì bèi xuăn míngdān de gōngshì)". Accessed February 16, 2014. http://www.fjwh.gov.cn/html/5/15/34077 20115301116.html.

Fujian Tourism Administration. 2007. "Report on the third strait travel fair (Guānyú dìsānjiè hăixiá lǘyóu bólănhuì zǒngjié qíngkuàng bàogào)". Accessed February 13, 2014. http://www.fjta.gov.cn/zwgk/200709/200709019909.html.

2011a. "Speech of Guo Hengming at the 2011 provincial tourism work conference (Guō héngmíng júzhăng zài 2011 nián quánshěng lǚyóu gōngzuò huìyì shàng de jiănghuà)". Accessed March 1, 2014. http://www.fjta.gov.cn/zwgk/201102/201102228656.html. 
2011b. "Study on vice-tourism department head Chen Yangbiao's arrival in Anxi (Shěng lǚyóujú fùjúzhăng chényángbiāo dào ānxī diàoyán)". Accessed February 15, 2014. http://www.fjta.gov.cn/zwgk/201105/201105058724.html.

2012. "Deputy Secretary Zheng Weirong went to the provincial broadcasting and television group to discuss cooperation (Zhèng wéiróng fùjúzhăng qiánwăng shěng guăngbò yǐngshì jítuán shāngtán hézuò)". Accessed February 11, 2014. http://www.fjta.gov.cn/zwgk/201211/2012112711168.html.

IHChina.cn. 2014a. "National Laws and Regulations (Guójiājí făguī wénjiàn)". Accessed September 23, 2014. http://www.ihchina.cn/show/feiyiweb/html/com.tjopen.define.po jo.feiyiwangzhan.FaGuiWenJian.faguiwenjianMore.html.

— 2014b. "Fujian Province (Fújiànshěng)". Accessed February 10, 2014. http://www.ihchina.cn/inc/zhanlan/zhanlangailan.jsp?class id=02 13.

IPinCH (Intellectual Property Issues in Cultural Heritage; Theory, Practice, Policy and Ethics). 2014. "Appropriation (?) of the Month: Cultural Tourism and Intangible Heritage". Accessed May 25, 2014. http://www.sfu.ca/ipinch/outputs/blog/appropriation-month-cultural-tourism-andintangible-heritage.

Heilmann, Sebastian. 2008. Policy Experimentation in China's Economic Rise. Studies on Contemporary International Development 43: 1-26.

Huang, Yijun. 2010. Quanzhou's ICH tourism development - from a tourist experience strengthening perspective (Quánzhōu fēiwùzhí wénhuà yíchăn de lǚyóu kāifā--yĭ zēngqiáng yóukè tǐyàn wèi shìjăo). Journal of Quanzhou Normal University (Social Science) (Quánzhōu shïfàn xuéyuàn xuébào (shèhuì kēxué)) 28: 125-129.

Jiangsu Culture Bureau. 2004. "2004 Work summary of Jiangsu Province Department of Culture (Jiāngsūshěng wénhuàtīng 2004 nián gōngzuò zǒngjié)". Accessed May 25, 2014. http://www.jscnt.gov.cn/gk/zd/fz/200711/t20071104 797.html. 
2005. "2005 Work summary of Jiangsu Province Department of Culture (Jiāngsūshěng wénhuàtīng 2005 nián gōngzuò zǒngjié)". Accessed My 24, 2014. http://www.jscnt.gov.cn/gk/zd/fz/200711/t20071104 796.html.

2007a. "Thoughts on Work of 2007 (2007 Nián gōngzuò sī)". Accessed May 22, 2014. http://www.jscnt.gov.cn/gk/zd/fz/200711/t20071104 799.html.

2007b. "Instructions on the preparation of "eleventh five-year plan" on cultural construction of Jiangsu Province (Guānyú biānzhì jiāngsū shěng wénhuà jiànshè "shíyīwǔ" guīhuà de shuōmíng)". Accessed $\quad$ May 2014. http://www.jscnt.gov.cn/gk/zd/fz/200711/t20071104 791.html.

2013. “Keeping memories, spreading beauty - Jiangsu province's 2013 exhibition review on intangible cultural heritage skills (Liú zhù jìyì chuánbò měilì - 2013 nián jiāngsūshěng fēiwùzhí wénhuà yíchăn jìyì dà zhăn huímóu)". Accessed May 15, 2014. http://www.jsqwfy.com/dtsx/1794.shtml.

Jiangsu Provincial Government. 2006. "Regulations of Jiangsu Province on Intangible Cultural Heritage Protection (Jiāngsūshěng fēiwùzhí wénhuà yíchăn băohù tiáolì)". Accessed May 19, 2014. http://www.jsqwfy.com/zcfg/iss/400.shtml.

2013a. "Regulations of Jiangsu Province on Intangible Cultural Heritage Protection (Jiāngsūshěng fēiwùzhí wénhuà yíchăn băohù tiáolì)". Accessed May 24, 2014. http://www.jsqwfy.com/zcfg/jss/1745.shtml.

2013b. "Notice on completing the reporting work on special funds for Jiangsu province's intangible cultural heritage protection (Guānyú zuòhăo 2013 niándù jiāngsūshěng fēiwùzhí wénhuà yíchăn băohù zhuānxiàng zījīn shēnbào gōngzuò de tōngzhī)". Accessed May 18, 2014. http://www.jscnt.gov.cn/zfxxgk/tzgg/201305/t20130515 17204.html.

Lenzerini, Federico. 2011. Intangible Cultural Heritage: The Living Culture of Peoples. The European Journal of International Law. 22 (1): 101-120. 
Li, Muhan. 1993. Discussing types and regional characteristics of folk tourism (Shìlùn mínsú lǚyóu de lèixíng jíqi qūyù tèzhēng). Folklore Studies (Mínsú yánjiū). 2: 95-98.

Liang, Yongjia. 2013. Turning Gwer Sa La Festival into Intangible Cultural Heritage: State Superscription of Popular Religion in Southwest China. China: An International Journal. 11: 58 75.

Lieberthal, Kenneth and Michael Oksenberg. 1988. Policy Making in China. Leaders, Structures and Processes. Oxford: Princeton University Press.

Lixinski,Lucas. 2011. Selecting Heritage: The Interplay of Art, Politics and Identity. The European Journal of International Law. 22 (1): 81-100.

Liu, Song, Jingqing Ma and Dongyang Lü. 2009. Research on Changzhou Intangible Cultural Heritage Tourism Development (Chángzhōushì fēiwùzhí wénhuà yíchăn lǚyóu kāifā yánjiū). Northern Economy (Qūyù jīngjï). 8: 58-59.

Mertha, Andrew. 2009. Fragmented Authoritarianism 2.0. The China Quarterly. 200: 995-1012.

Murphy, J. David. 1994. An Annotated Chronological Index of People's Republic of China Statutory and other Materials Relating to Cultural Property. International Journal of Cultural Property. 3: 159-168.

Nanjing Culture Bureau. 2005. “The city's main cultural work situation since 2005 (2005 Nián yilái quánshì wénhuà gōngzuò zhǔyào qíngkuàng)". Accessed June 3, 2014 . http://www.nanjing.gov.cn/njszf/bm/wgxj/200801/t20080123 1666766.html.

2006. “Opinion on developing Nanjing municipalities ICH survey work (Guānyú kāizhăn nánjīngshì fēiwùzhí wénhuà yíchăn pǔchá gōngzuò de yìjiàn)". Accessed June 5, 2014 . http://www.nanjing.gov.cn/njszf/bm/wgxi/200801/t20080130 1666951.html.

2007. “Nanjing Municipality's 2006 completed status on main work on cultural system and thoughts on main work in 2007 (Nánjīngshì wénhuà xìtǒng 2006 nián zhǔyào gōngzuò wánchéng 
qíngkuàng hé 2007 nián zhǔyào gōngzuò sīlù)". Accessed June 4, 2014. http://www.nanjing.gov.cn/njszf/bm/wgxj/200802/t20080228 1666769.html.

2011. “Nanjing Municipality's Five-Year Plan on Cultural Development (Nánjīngshì "shí'èrwǔ" wénhuà fāzhăn guīhuà)". Accessed June 6, 2014 . http://www.nanjing.gov.cn/njszf/bm/wgxi/201110/t20111008 1666826.html.

Phoenix China. 2009. "Beauty of China - Series 1". Accessed May 7, 2014. http://www.phoenixtv-distribution.com/products/detail/238/238/93/pcategory:95/lang:eng.

PRC Ministry of Culture. 2007. "MOC Office's response on the report on Minnan cultural environmental protection (Wénhuàbù bàngōngtīng guānyú mǐnnán wénhuà shēngtài băohù bàogào de fùhán)". Accessed May 25, 2014. http://govinfo.nlc.gov.cn/search/htmlflash 4Radar?docid=2211832.

2009. "MOC and NTA Leading opinion on advancing joint development of culture and tourism leadership (Wénhuàbù guójiā lǚyóujú guānyú cùjìn wénhuà yǔ lüyóu jiéhé fāzhăn de zhǐdăo yijiàn)". Accessed May 27, 2014. http://www.gov.cn/zwgk/200909/15/content 1418269.htm.

2012. "Document ““Twelfth five-year plan” on doubling cultural industry” (““Shi'èrwǔ” shíqí wénhuà chănyè bèizēng jìhuà" quánwén)". Accessed May 18, 2014. http://www.wenming.cn/whtzgg pd/yw whtzgg/201203/t20120301 5293695. shtml.

Quanzhou Municipal Government. 2003. “2003 municipal work report (2003 Nián quánzhōu shìzhèngfǔ gōngzuò bàogào)". Accessed $\quad$ February 2014. http://www.fjaz.gov.cn/E1BC60B1A4D24B149EAC9194154CE643/82D511D5A211FB1D06E74 C272127C1EC.html.

2014. "Municipal work report (Shìzhèngfǔ gōngzuò bàogào) (Issues 2003-2013)". Accessed February 23, 2014. http://www.fjqz.gov.cn/E1BC60B1A4D24B 149EAC9194154CE643/index.html. 
Sichuan Provincial Government. 2010. "Sichuan Province Culture Department on Ministry of Culture's Notice on Establishing National Demonstration Bases for ICH Protection" (Sìchuānshěng wénhuàtīng zhuănfā "wénhuàbù bàngōngtīng guānyú kāizhăn guójiājí fēiwùzhí wénhuà yíchăn shēngchănxìng băohù shìfàn jīdì jiànshè de tōngzhī” de tōngzhī)". Accessed May 19, 2014. http://www.sc.gov.cn/zwgk/gggs/wh/201011/t20101117 1082734.shtml.

Smith, Laurajane. 2006. Uses of Heritage. London and New York: Routledge.

Song, Bin. 2012. National Intangible Cultural Heritage of the Survival Mode of Travel - A National "Non-legacy" for the Case of Changzhou Comb (Guójiā fēiwùzhí wénhuà yíchăn de lǚyóu huà shēngcún móshì yánjiū - yĭ guójiājí "fēi yí" chángzhōu shūbì wéi lì). Journal of Jiangsu Teachers University of Technology (Jiāngsū jisshù shïfàn xuéyuàn xuébào). 18: 77-80.

State Council of the PRC. 2006. "Interim measures on national ICH protection and management (Guójiājí fēiwùzhí wénhuà yíchăn băohù yù guănlì zhànxíng bànfă)". Accessed March 23, 2014. http://www.gov.cn/gongbao/content/2007/content 751777.htm.

Sun, Li, Kaihao Wang, Jia Cui, Yiqi Yan and Palden Nyima. 2012. "From TV title to national policy". China Daily. January 21, 2014. http://usa.chinadaily.com.cn/epaper/2014$\underline{01 / 21 / \text { content } 17248474 . h t m}$.

Svensson, Marina. 2006. In the Ancestors' Shadow: Cultural Heritage Contestations in Chinese Villages. Working Paper in Contemporary Asian Studies (Lund University). 17: 1-60.

Rubenstein, Murray. "Medium/Message" in Taiwan's Mazu Cult-Centers: Using "Time, Space and Word" to Foster Island-Wide Spiritual Consciousness and Local, Regional and National Forms of Institutional Identity. In Religion and the Formation of Taiwanese Identities, edited by Peter Katz, Murray Rubenstein. New York: Palgrave Macmillan.

Tongnj.com. "Origins of Nanjing's name 'Jinling' (Nánjīng míngchēng "jīnlíng" de yóulái)". Accessed March 3, 2014. http://www.tongnj.com/1njgds/qhwjnbc/114.html . 
UNESCO. 1972. "Convention Concerning the Protection of the World Cultural and Natural Heritage". January 20, 2014. http://whc.unesco.org/en/conventiontext/.

UNESCO. 1989. "Recommendation on the Safeguarding of Traditional Culture and Folklore". Accessed January 20, 2014. http://portal.unesco.org/en/ev.phpURL ID=13141\&U $\underline{R L} \mathrm{DO}=\mathrm{DO}$ TOPIC\&URL SECTION=201.html.

UNESCO. 2001. "Proclamation of Masterpieces of the Oral and Intangible Heritage of Humanity". Accessed January 21, 2014. http://www.unesco.org/bpi/intangible heritage/backgrounde.htm.

UNESCO. 2003. "Text of the Convention for the Safeguarding of Intangible Cultural Heritage". Accessed March 14, 2014. http://www.unesco.org/culture/ich/index.php?lg=en\&pg=00006.

UNESCO. 2015a. "Convention for the Safeguarding of Intangible Cultural Heritage (Băohù fēi wùzhí wénhuà yíchăn gōngyuē)", Accessed December 26, 2015. http://unesdoc.unesco.org/images//0013/001325/132540c.pdf

UNESCO. 2015b. “Protecting' or 'safeguarding'?". Accessed December 27, 2015, http://www.unesco.org/culture/ich/en/faq-00021.

Vecco, Marilena. 2010. A definition of cultural heritage: From the tangible to the intangible. Journal of Cultural Heritage. 11: 321-324.

Wang Degang. 2003. A study of a folk tourism development model - based on a discussion of a practical folk resources development and utilization model (Mínsú lǚyóu kāifā móshì yánjiū—jīyú shíjiàn de mínsú zīyuán kāifā lìyòng móshì tàntǎo). Folklore Studies (Mínsú yánjiū). 1: 51-58.

Wang, Xi. 2011. On the Intangible Cultural Heritage Tourism Development in Nanjing Qinhuai River Basin (Qiǎntán nánjīng qínhuáihé liúyù fēiwùzhí wénhuà yíchăn de lüyóu kāifā). Social Science Review (Shèkēzònghéng). 26: 84-85. 
Wei, Chengyuan. 2012. A transmission analysis of $\mathrm{ICH}$ tourismization focusing on the product perspective - A case Study of Quanzhou Nanyin Music (Chănpǐn shijiǎo xiàde fēiwùzhí wénhuà yíchăn lüyóuhuà chuánchéng fēnxī--yĭ quánzhōu nányīn wéi lì). Journal of Xiamen University of Technology (Xiàmén līgōng xuéyuàn xuébào). 20: 1-5.

Xu, Congyao. 2013. The Research on Nanjing Brocade's Tourist Souvenirs Development (Nánjīng yúnjǐn lǚyóu jìniànpǐn de kāifā shèjì). Design (Shèjì). 6: 171-172.

Yan, Haiming, 2015. World Heritage as discourse: knowledge, discipline and dissonance in Fujian Tulou sites. International Journal of Heritage Studies. 21 (1): 65-80.

Yu, Hua, 2015. A vernacular way of "safeguarding" intangible heritage: the fall and rise of rituals in Gouliang Miao village. International Journal of Heritage Studies, 21 (10): 1016-1035.

Zhu, Yujie, 2015. Cultural effects of authenticity: contested heritage practices in China. International Journal of Heritage Studies. 21 (6): 594-608. 